\title{
ON THE LONG-TERM BEHAVIOUR OF GLACIAL ICE UNDER MOVING TRAFFIC LOAD: A CASE STUDY
}

\author{
By S. G. VOMBATKERE
}

(Structural Engineering Laboratory, Department of Civil Engineering, Indian Institute of Technology, Madras 600 036, India)

ABSTRACT. A Bailey bridge built on a permanent ice body at an altitude of $5580 \mathrm{~m}$ above mean sea-level has been carrying regular traffic of 7 tonne motor vehicles for over 2 years. The problems posed by the ice body, its behaviour under the load of the bridge and traffic, its summer and winter behaviour, and the problems posed in the construction and maintenance of the bridge are studied and discussed.

RÉSUMÉ. Comportement à long terme de la glace de glacier soumise au trafic automobile: étude d'un cas. Un pont Bailey construit sur une masse de glace permanente à $5580 \mathrm{~m}$ d'altitude a supporté un trafic régulier de véhicules de 7 tonnes pendant plus de 2 ans. On étudie les problèmes

\section{INTRODUCTION}

In some of the snow-bound glacierized regions of high mountains, roads have to pass over ice. In most cases, the road alignment is selected to avoid large stretches of ice; smaller ice bodies are either not permanent (forming only in winter) or can be easily destroyed, and the road constructed over them.

Bridges and other devices were constructed on ice (Playfair, 1957) during World War II in winter; notably, the winter road over Lake Ladoga during the seige of Leningrad and, more recently, the use of the tactical ribbon bridge indicate that long-term retention of these structures is usually impossible due to ablation of the ice mass, leading to loss of structural stability. Hence, these structures have to be dismantled once the need for them has passed, or before the spring thaw.

The ice body described here is a large perennial body which supports a Bailey bridge. The bridge is unique in that it is a semi-permanent structure that does not have to be dismantled and is also the highest motorable bridge in the world.

In one of the glacierized, mountainous, high-altitude, semi-arid areas in the north of India, the road goes through a pass at an altitude of $5603 \mathrm{~m}$ and over an ice body (Fig. 1). The ice body covers the mountainside for about $100 \mathrm{~m}$ above the road and $35 \mathrm{~m}$ below it; the length of the road passing over the ice body is about $80 \mathrm{~m}$. This section was mostly bare ice and was an obstacle to be negotiated with great care. Spreading of earth and boulders had been resorted to in order to improve wheel traction on the ice surface. This resulted in increased melt of the ice surface due to increased heat absorption by the spread material from incident radiation, and was manifest by a dip in the road surface (Fig. 2).

With the passage of time and vehicular traffic this dip became increasingly pronounced. Further filling of this dip with boulders only increased the ice melt and made the surface a morass of frozen earth and ice-covered slippery boulders which was even more difficult to negotiate, while the up-gradient ( 1 in 5 , approximately) of the dip in either direction was almost impossible, even for a light four-wheel-drive vehicle, to climb out under its own power. posés par la masse de glace, son comportement sous le poids du pont et de la circulation, son comportement estival et hivernal, les problèmes de construction et d'entretien du pont.

ZUSAMMENFASSUNG. Das Langzeitverhalten von Gletschereis unter bewegten Verkehrslasten: eine Fallstudie. Eine Bailey-Brücke über einen dauerhaften Eiskőrper in einer Meereshöhe von $5580 \mathrm{~m}$ hatte zwei Jahre lang regelmässigen Verkehr von $7 \mathrm{t}$-Motorfahrzeugen aufzunehmen. Die Probleme, die der Eiskörper aufwarf, sein Verhalten unter der Last der Brücke und des Verkehrs, sein Verhalten in Sommer und Winter und die Probleme des Baus und Unterhalts der Brücke werden untersucht und diskutiert.

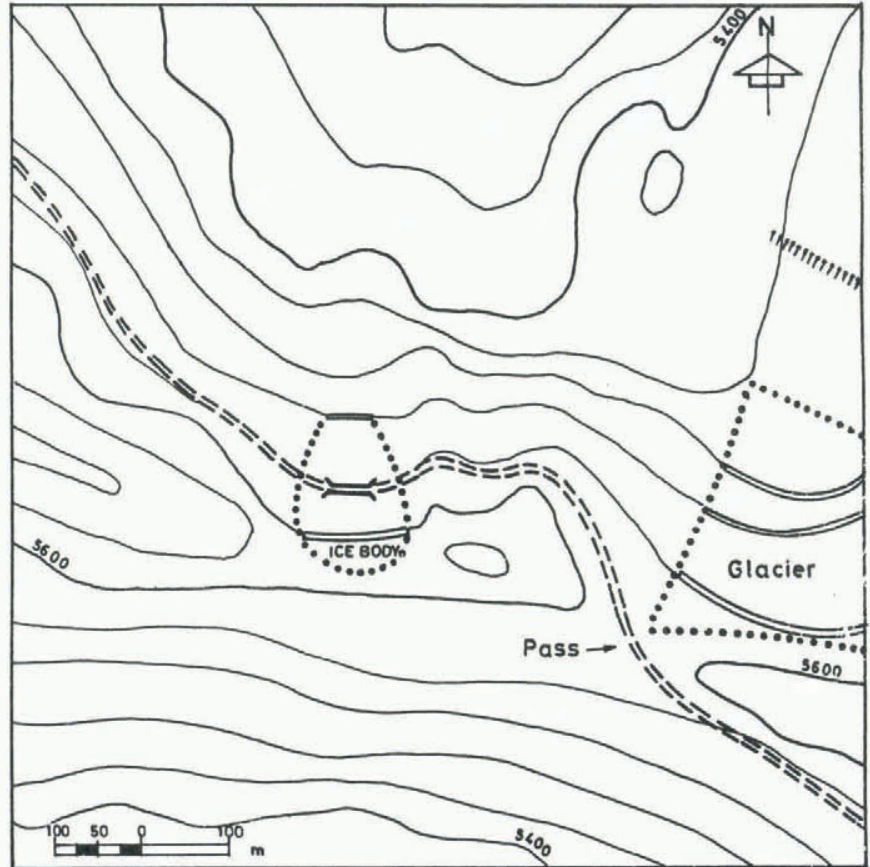

Fig. 1. Sketch map of the ice body showing the location of the bridge.

Passage of traffic over the route was very severely restricted due to this ice mass; the surface-traction difficulty was compounded by steep approaches to the dip and by loss of engine power due to high altitude.

Before construction of the bridge, vehicles passing across the ice body had to be winched out of the steep dip that had been created by ablation. A bridge (Figs 3 and 4) constructed on the ice body has removed the restriction of traffic to passage at this point on the route. 


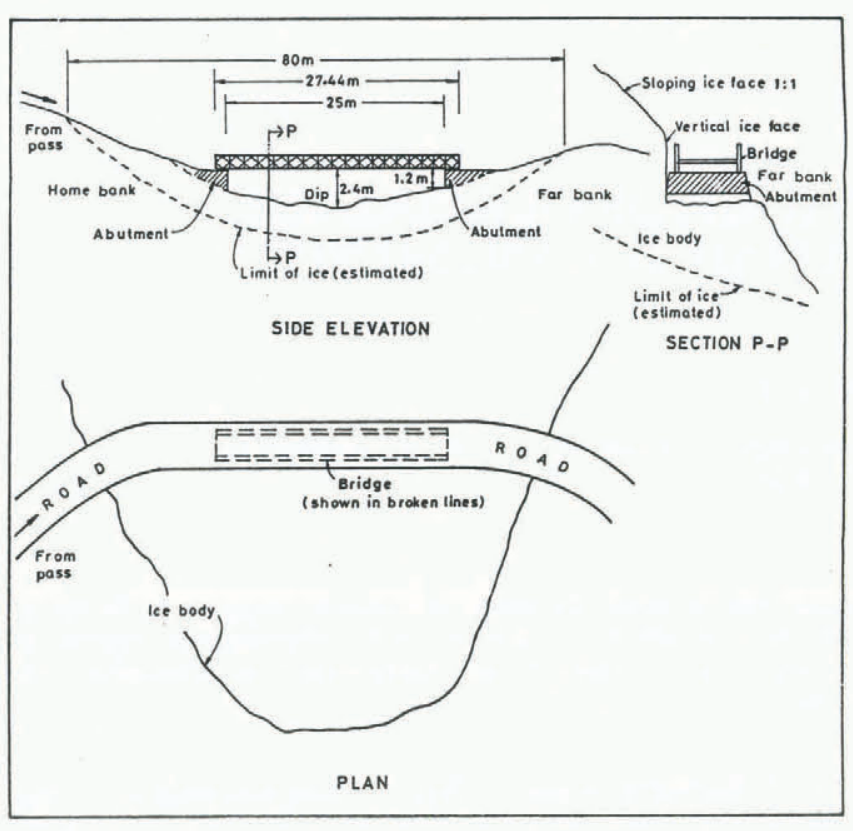

Fig. 3. The bridge across the ice body.

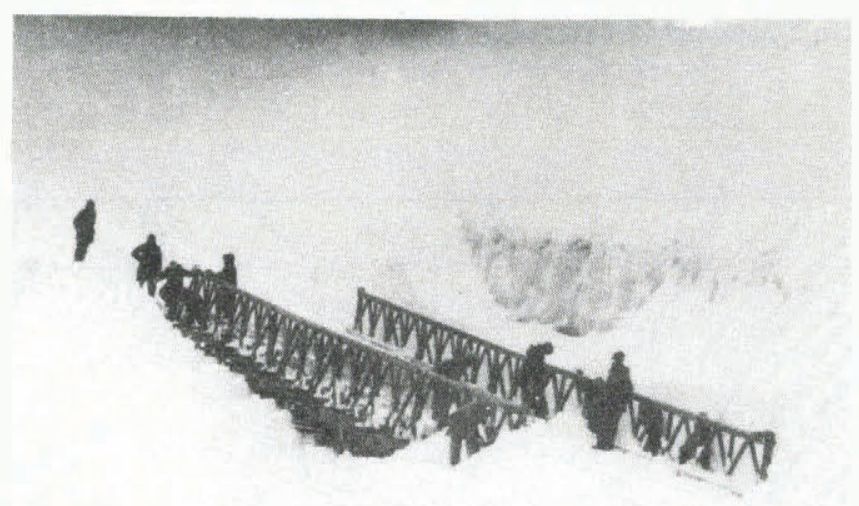

Fig. 2. Details of the bridge across the ice body.

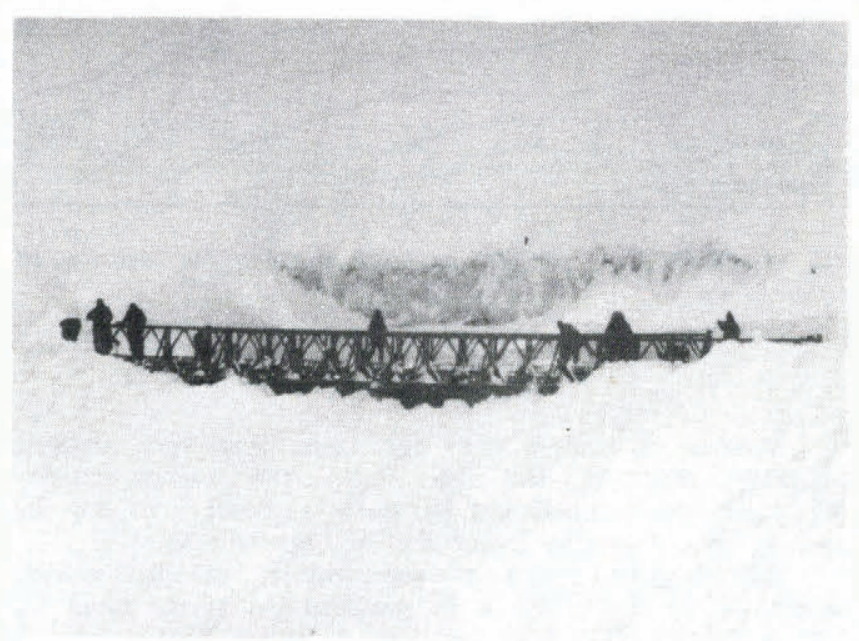

Fig. 4. The bridge across the ice body.

\section{ALTERNATIVES}

In order to overcome this restriction to road traffic, a re-alignment of the road at an estimated cost of several million rupees was proposed. This proposal was based on the recommendation of geologists who were of the opinion that the ice body was in a state of flow.

The alternative to the re-alignment (which involved new road work) was construction of a bridge spanning the $80 \mathrm{~m}$ length of the ice body. This was rejected due to site restrictions of horizontal curve and the large span; the construction of a bridge on the ice itself was ruled out at the time because the ice body was thought to be mobile.

\section{PERIOD OF OBSERVATION}

The road over the ice body had existed for nearly 6 years when the bridge was constructed in 1982. Due to the very low traffic density and the spreading of earth and boulders to improve traction, the dip in the road surface (Fig. 2) at the centre of the ice body did not pose much problem until 1980. After much deliberation, the ice body was studied carefully by the author during May-August 1982, and in August 1982 the bridge was built on dry stone masonry abutments which were themselves based on the ice body. The bridge was in use from August to late October 1982 and again from June 1983 to the present time; the ice body was under regular observation by the author to determine the safety and stability of the bridge, and it was also observed for any signs of failure or movement. The bridge was observed with an engineer's theodolite for stability of its position and attitude.

\section{CHARACTERISTICS OF THE ICE BODY}

Location. The ice body is located in a mountainous glacierized area in northern India at an altitude of $5580 \mathrm{~m}$ a.m.s.1. (Fig. 1).

Size. It covers a north-facing mountainside about $100 \mathrm{~m}$ above the road and $35 \mathrm{~m}$ below it. About $80 \mathrm{~m}$ of the road passes over the ice body. The thickness of the ice was not determined.

Movement. In the opinion of glaciologists, the ice body was in a state of flow; observations during May-August 1982, from the stand-point of the engineer, were adequate to ascertain its stability within engineering limits. The following discussion clarifies this point:

(a) The road surface over the ice was thought to be sinking; this was not true. The increase in the steepness of the "dip" was due to increased melting which, in turn, was due to increased heat absorption by the earth fill, wheel pressure, and abrasion.

(b) The ice body was thought to be moving laterally because the vertical ice face at the side of the roadway was apparently moving and reducing the road width, and had to be cut back to maintain the road width; this was not true. The apparent movement of the vertical ice face was due to melting of ice on the slope above due to radiation and the melt water refreezing on the vertical ice face. This was substantiated by the fact that the entire ice body is on a north-facing slope and the vertical ice face receives no radiation, even in the summer, when the slope above receives sunshine. (It was later observed, in the winter of 1983-84, that the ice face shows no build-up of ice; this is because there is no winter melt on the upper slope.) The fact that there is no lateral movement was also determined from the observation that the centre line and the valley edge of the road over the ice were aligned with the centre line and valley edge of the road segments on both sides of the ice body. 
Summer behaviour

In winter, the maximum and minimum temperatures are about $-25^{\circ} \mathrm{C}$ and $-40^{\circ} \mathrm{C}$, respectively, while in summer the maximum and minimum temperatures are about $+15^{\circ} \mathrm{C}$ and $+5^{\circ} \mathrm{C}$ near the ice body. The vertical ice face never receives sunshine throughout the year; the effects of wind chill are well known and can lower the effective temperature by $10^{\circ}-20^{\circ} \mathrm{C}$ depending on the wind speed. Thus, even at the height of summer (July-August), the surface temperatures can be freezing, while high temperatures can cause considerable melt of the overlying snow and the ice. Due to the melt of snow and ice from the upper parts of the ice body during the summer, a substantial quantity of water flows down the vertical ice face and across the road. A high proportion of this water flows under the ice along the length of the road, causing some erosion. The surface water is diverted manually to flow to the centre of the bridge span and across the road through a rough channel so as not to affect the abutments which would otherwise be subjected to scour.

\section{Winter behaviour}

The bridge was constructed in August 1982 but it was dismantled in late October 1982 mainly because the winter behaviour of accumulated snow on the ice body above the bridge had not been studied. Winter observations convinced the author that only minor snow slides would descend from the ice body and would pose no serious danger to the bridge. Once the bridge was reconstructed in June 1983, it was allowed to remain in place and was in use during the winter of 1983-84 and is still in use without interruption.

\section{ICE}

The ice body has a density of about $900 \mathrm{~kg} / \mathrm{m}^{3}$. The ice is homogeneous, unfractured, green, and bubble-free; it is very difficult to cut either with a bulldozer blade or with a pick-axe. Ice removal to keep the bridge free was done before construction with small charges of low explosive in shallow holes drilled by pneumatic jack-hammers; after construction, pick-axes were used. At altitudes of $5580 \mathrm{~m}$, the output both of men and machines is, at best, $60 \%$ of their sea-level output.

\section{Bearing capacity of the ice}

With a bridge weight of $177 \mathrm{kN}$ resting on abutments each of size $4.8 \mathrm{~m} \times 1.2 \mathrm{~m} \times 1.8 \mathrm{~m}(224 \mathrm{kN}$ each) and a vehicle load of $98 \mathrm{kN}$, the load at the base of each abutment $=(177 / 2)+224+98=410 \mathrm{kN}$ over an area of $4.8 \mathrm{~m} \mathrm{x} 1.8 \mathrm{~m}$. Hence, the bearing pressure $410 /(4.18 \times$ $1.8)=47.5 \mathrm{kN} / \mathrm{m}^{2}$. This loading is borne well by the ice body.

\section{Drainage}

Melt water from the surface of the upper part of the ice body finds its way down to the roadway. The water flows down the vertical ice face and under the ice of the roadway, and re-appears on the lower side as streams about $3 \mathrm{~m}$ below the roadway. It was essential to cut a surface channel across the ice at mid-span of the bridge to prevent water from flowing under the ice near the abutments and thus damaging the interface between earth and ice.

\section{THE BRIDGE}

It was impractical to construct a bridge spanning the ice body due to site restrictions of space, curvature, and slope. An equipment bridge was also decided upon as it could be easily dismantled. With the high cost of road realignment and the long period required for its completion, the only immediate solution to the problem of passage of traffic was to construct a shorter-span bridge with its abutments on the ice. The decision to construct the bridge was taken after a study of the characteristics of the ice body, and the author was convinced of its feasibility. The bridge was first constructed in August 1982 and, after a 3 month period of use in 1982, was dismantled and reconstructed in June 1983 from which date it is still in use, having had uninterrupted service of over 2 years at the time of writing (Vombatkere, in press).

The maintenance of the bridge involves preventing the ice from touching or enveloping its transom ends by manually cutting away ice and keeping the drains clear to ensure that melt water does not scour the abutments. The four corners of the bridge were observed with a levelling instrument, with respect to a temporary bench mark, to determine any movement or change in attitude of the bridge. During the initial month of service, measurements were made on alternate days, and later were made once a month; no movement of the bridge was detected.

\section{CONCLUSION}

The construction and service of this motorable bridge under extreme conditions of high altitude and cold have proved beyond doubt the suitability of flawless, unfractured glacial ice as a foundation for moving traffic loads, thus introducing an economical and time-saving method for improving mobility in glacierized regions.

\section{ACKNOWLEDGEMENTS}

The encouragement and help by Brigadier K.K. Malhotra, Chief Engineer, Project Beacon of the Border Road Organization, is gratefully acknowledged; without his assistance and guidance this paper could not have been written. To the hardworking Pioneers of the Border Road Organization goes the credit for constructing the world's highest motorable bridge under the most arduous conditions, to make reality of the germ of a bold decision.

\section{REFERENCES}

Playfair, E. W. 1957. Military engineering. Vol. 3. Bridging. Pt. 1. General. London, Her Majesty's Stationery Office.

Vombatkere, S.G. In press. Bridge resting on an ice body at high altitude. Journal of the American Society of Civil Engineers, Construction Division. 